\title{
Formation kinetics and mechanisms of ozone and secondary organic aerosols from photochemical oxidation of different aromatic hydrocarbons: dependence on $\mathrm{NO}_{x}$ and organic substituents
}

\author{
Hao Luo ${ }^{1,2,}$, Jiangyao Chen ${ }^{1,2, \star}$, Guiying $\mathrm{Li}^{1,2}$, and Taicheng $\mathbf{A n}^{1,2}$ \\ ${ }^{1}$ Guangdong Key Laboratory of Environmental Catalysis and Health Risk Control, Guangdong-Hong Kong-Macao Joint \\ Laboratory for Contaminants Exposure and Health, Institute of Environmental Health and Pollution control, Guangdong \\ University of Technology, Guangzhou 510006, China \\ ${ }^{2}$ Guangzhou Key Laboratory of Environmental Catalysis and Pollution Control, Key Laboratory of City Cluster \\ Environmental Safety and Green Development, School of Environmental Science and Engineering, \\ Guangdong University of Technology, Guangzhou 510006, China \\ These authors contributed equally to this work.
}

Correspondence: Taicheng An (antc99@gdut.edu.cn)

Received: 13 January 2021 - Discussion started: 25 January 2021

Revised: 26 March 2021 - Accepted: 29 March 2021 - Published: 18 May 2021

\begin{abstract}
Aromatic hydrocarbons (AHs) contribute significantly to ozone and secondary organic aerosol (SOA) formation in the atmosphere, but their formation mechanisms are still unclear. Herein, the photochemical oxidation of nine AHs was investigated in a chamber. Only a small amount of ozone was produced from the direct photochemical oxidation of AHs, while a lower number of AH substituents resulted in higher concentrated ozone. Addition of $\mathrm{NO}_{x}$ increased ozone and SOA production. The synergetic effect of accelerated $\mathrm{NO}_{2}$ conversion and $\mathrm{NO}$ reaction with AHs boosted ozone and volatile intermediate formation. Promoting $\mathrm{AH}$ concentration in the $\mathrm{VOC} / \mathrm{NO}_{x}$ ratio further increased formation rates and concentrations of both ozone and SOA. Additionally, ozone formation was enhanced with increasing AH substituent number but negligibly affected by their substituent position. Differently, SOA yield decreased with an increased substituent number of AHs but increased with ortho-methylgroup-substituted AHs. Model fitting and intermediates consistently confirmed that increasing the substituent number on the phenyl ring inhibited generation of dicarbonyl intermediates, which however were preferentially produced from oxidation of ortho-methyl-group-substituted AHs, resulting in different changing trends of the SOA yield. The restrained oligomerization by increased substituent number was another main cause for decreased SOA yield. These results are help-
\end{abstract}

ful to understand the photochemical transformation of $\mathrm{AHs}$ to secondary pollutants in the real atmosphere.

\section{Introduction}

As an abundant group of volatile organic compounds (VOCs), aromatic hydrocarbons (AHs) are important precursors of ozone $\left(\mathrm{O}_{3}\right)$ and secondary organic aerosols (SOAs) in the atmospheric environment (Peng et al., 2017; Tong et al., 2020), directly or indirectly threatening air quality and public health (Henze et al., 2008; Lane et al., 2008; Yang et al., 2016). Atmospheric AHs mainly come from anthropogenic sources, such as industrial emission and motor vehicle emission (Luo et al., 2020a; Sun et al., 2018; Chen et al., 2020; An et al., 2014; He et al., 2015), and these emitted AHs are commonly composed of a single phenyl ring with fewer than four methyl groups (e.g., toluene, xylene) or ethyl groups (e.g., ethylbenzene) (Han et al., 2019; Hu et al., 2015; Chen et al., 2019). It is also found that photochemical oxidation of these AHs is sensitive to reaction conditions (e.g., VOC / $\mathrm{NO}_{x}$ ratio; Odum et al., 1996; Metzger et al., 2008; Bloss et al., 2005a; Carter and Heo, 2013), ultimately influencing the formation kinetics and mechanisms of $\mathrm{O}_{3}$ and $\mathrm{SOA}$ from $\mathrm{AH}$ 
oxidation (Borrás and Tortajada-Genaro, 2012; Sato et al., 2010; Cocker et al., 2001; Ji et al., 2017; Jia and Xu, 2018).

Previous experimental simulation studies have confirmed that a relatively high $\mathrm{VOC} / \mathrm{NO}_{x}$ ratio had an inhibitory effect on SOA productivity (Wang et al., 2015), while the VOC $/ \mathrm{NO}_{x}$ ratio might also influence $\mathrm{O}_{3}$ formation (Wang et al., 2016). From field observations, the actual ratio of $\mathrm{VOC} / \mathrm{NO}_{x}$ in the atmosphere always changes with the variation of the seasons (Geng et al., 2008; Zou et al., 2015; Li et al., 2013; Seinfeld, 1989). Nevertheless, although it is of important environmental significance, studies about the influence of VOC / $\mathrm{NO}_{x}$ ratio on photochemical oxidation of AHs to form $\mathrm{O}_{3}$ and SOA are mostly focused on the varied $\mathrm{NO}_{x}$ concentration. The effects of AH content as well as substitute groups of AHs to the formation kinetics and mechanisms of $\mathrm{O}_{3}$ and SOA have still not been studied. Therefore, in view of the complexity of the real atmosphere, it is very necessary to effectively simulate atmospheric photochemical reactions at different $\mathrm{VOC} / \mathrm{NO}_{x}$ ratios in the laboratory smog chamber and explore the formation kinetics and mechanisms of $\mathrm{O}_{3}$ and SOA from AHs at different concentrations.

Usually, OH-initiated reactions have been confirmed to dominate in AH photochemical oxidation ( $\mathrm{Ji}$ et al., 2018), in which the reaction rate constant increases with increased substituent number of AHs (Atkinson and Arey, 2003; Aschmann et al., 2013; Glasson and Tuesday, 1970). The important role of substituent position has also been observed in the $\mathrm{OH}$-initiated alkane and alkene oxidation (Atkinson, 2007; Ziemann, 2011). All these previous studies inspire us that the influence of substituents, including the number and position, on the photochemical transformation of $\mathrm{AHs}$ to $\mathrm{O}_{3}$ and SOA cannot be ignored. However, although both $\mathrm{O}_{3}$ and SOA generated from different AHs have been studied in laboratory smog chamber simulations, the role of $\mathrm{AH}$ substituents in the formation kinetics and mechanisms of $\mathrm{O}_{3}$ and $\mathrm{SOA}$, as well as their relationship with the oxidation intermediates, has not been systematically investigated and established.

In this work, nine AHs with different substituent numbers and positions (e.g., benzene, toluene, ethylbenzene, $m$-xylene, $o$-xylene, $p$-xylene, 123-trimethylbenzene, 124trimethylbenzene, 135-trimethylbenzene) were chosen to study their photochemical oxidation behavior in an indoor smog chamber system to compare the formation activity in $\mathrm{O}_{3}$ and SOA. The influences of $\mathrm{NO}_{x}, \mathrm{AH}$ concentration, and $\mathrm{AH}$ substituent on the formation kinetics of $\mathrm{O}_{3}$ and SOA were studied in detail. All volatile intermediates were qualitatively and quantitatively analyzed online to propose their potential contribution to the formation of $\mathrm{O}_{3}$ and SOA. The relationship between $\mathrm{AH}$ structure, intermediates, and production of $\mathrm{O}_{3}$ and SOA was established to reveal the transformation mechanisms of $\mathrm{AHs}$ to $\mathrm{O}_{3}$ and SOA. The results of this work will further elucidate the photochemical behavior of AHs in the atmosphere and provide reliable experimental data for modeling and prediction in the future.

\section{Experimental}

\subsection{Photochemical oxidation experiment}

All experiments were conducted in a GDUT-DRC dualreactor chamber with two $2 \mathrm{~m}^{3}$ pillow-shaped reactors; a detailed description of the reactor is reported in our earlier work (Luo et al., 2020b). The experimental relative humidity (RH) and temperature were set to $<5 \%$ and around $303 \pm 1 \mathrm{~K}$, respectively. No inorganic seed aerosol was supplied in this work. A total of 60 black lamps $(40 \mathrm{~W}, \mathrm{~F} 40 \mathrm{BL}$, GE, USA) were equipped to provide the UV light source, and the light intensity in the dual reactor was determined to be $0.161 \mathrm{~min}^{-1}$ (left) and $0.169 \mathrm{~min}^{-1}$ (right) using the $\mathrm{NO}_{2}$ photolysis rate constant (Luo et al., 2020b). The center of the UV lamp wavelength was $360 \mathrm{~nm}$.

Nine AHs (benzene, 99.5\%; toluene, 99.0\%; ethylbenzene, $99.8 \%$; $m$-xylene, $99.0 \%$; $o$-xylene, $99.0 \%$; p-xylene, $99.0 \% ; \quad$ 1,2,3-trimethylbenzene (123-TMB), 90.0\%; 1,2,4-trimethylbenzene (124-TMB), 98.0\%; 1,3,5trimethylbenzene (135-TMB), 97.0\%) purchased from Aladdin Industrial Co., Ltd. (USA) and a certain amount of $\mathrm{NO}_{2}$ were directly injected into the reactor to conduct the photochemical oxidation experiments. Before turning on the light, all $\mathrm{AHs}$ and $\mathrm{NO}_{2}$ were injected with the background gas flow and adjusted to stabilize for $1 \mathrm{~h}$. Typical experimental conditions (e.g., concentrations of AHs and $\mathrm{NO}_{x}$, VOC $/ \mathrm{NO}_{x}$ ratio, $\mathrm{RH}$, and temperature) of this study for nine AHs are supplied in the Supplement in Table S1.

\subsection{Organic gas measurement}

The concentrations of AHs and their oxidation products were all measured online using a proton-transfer reaction timeof-flight mass spectrometer (PTR-ToF-MS; Ionicon Analytik Inc., Austria). In the setting model, all gaseous organics with proton affinity greater than $\mathrm{H}_{2} \mathrm{O}$, including $\mathrm{AHs}$, hydrocarbons, acids, and carbonyl groups, were all measured quantitatively and qualitatively. The processing software TOF-DAQ (Tofwerk AG, Switzerland) recorded the material with $m / z \leq 240$, and the original signal strength was converted into parts per billion (ppb) concentration by a formula (Lindinger et al., 1998). Before sampling and measurement, PTR-ToF-MS was calibrated once a week throughout the measurement period (Han et al., 2019). The detection limit of PTR-ToF-MS was $<20$ ppt for $m / z 79$ and $<10 \mathrm{ppt}$ for $m / z 181$ averaged over $1 \mathrm{~min}$. Detailed parameters of the instrument and the yield calculation formula of products are given in the Supplement.

\subsection{Inorganic gas measurement}

The real-time concentrations of $\mathrm{NO}, \mathrm{NO}_{2}$, and $\mathrm{NO}_{x}$ were all spontaneously monitored with an $\mathrm{NO}_{x}$ analyzer (Model $42 \mathrm{i}$, Thermo Scientific Inc., USA), and the real-time concentration of $\mathrm{O}_{3}$ was monitored with an $\mathrm{O}_{3}$ analyzer (Model 49i, 
Thermo Scientific Inc., USA). The detection limits of the $\mathrm{NO}_{x}$ and $\mathrm{O}_{3}$ analyzers were $<0.4 \mathrm{ppb}$ averaged over $1 \mathrm{~min}$ and $0.5 \mathrm{ppb}$, respectively. All devices were calibrated weekly using a gas calibrator (Model 146i, Thermo Scientific Inc., USA).

\subsection{Particle measurement}

Particle size distribution was measured by a scanning mobility particle sizer spectrometer (SMPS; TSI Inc., USA) equipped with electrostatic classifiers (ECs; Model 3082, TSI Inc., USA) and a long differential mobility analyzer (DMA) (Model 3081, TSI Inc., USA) or an optional nanoDMA (Model 3085, TSI Inc., USA) and a condensation particle counter (CPC; Model 3776, TSI Inc., USA). The velocities of sheath gas and aerosol flows were set at 3.0 and $0.3 \mathrm{~L} \mathrm{~min}^{-1}$, respectively. Under this setting, the particle size range was observed from 13.8 to $723.4 \mathrm{~nm}$. The yield calculation formula of SOA is given in the Supplement.

\section{Results and discussion}

\subsection{Formation kinetics and mechanisms of $\mathrm{O}_{3}$ and SOA without $\mathrm{NO}_{x}$}

The direct photochemical oxidation of nine AHs was first conducted to evaluate the formation potential of $\mathrm{O}_{3}$ and SOA. No SOA was detected within 480 min reaction duration. The $\mathrm{O}_{3}$ concentration increased steadily from 0 to $16 \mathrm{ppb}$ for $135-\mathrm{TMB}$ and $28 \mathrm{ppb}$ for ethylbenzene within $420 \mathrm{~min}$ (Fig. 1a). The peak concentration of $\mathrm{O}_{3}$ for these nine AHs followed the trend of (ethylbenzene, toluene, benzene, $23-28 \mathrm{ppb})>(m-, o-, \quad p$-xylene, $18-$ $21 \mathrm{ppb})>(123-$, 124-, 135-TMB, 16-20 ppb). Clearly, a lower number of $\mathrm{AH}$ substituents resulted in the generation of higher concentrated $\mathrm{O}_{3}$. This may be because the substituent number of AHs determined their reactivity, while the reaction rate constants with $\cdot \mathrm{OH}$ could be applied to evaluate the reactivity. Previous studies indicated that the rate constants of AHs with $\cdot \mathrm{OH}$ were found to follow the order of toluene $(5.61 \pm 0.08) \times 10^{-12} \mathrm{~cm}^{3}$ molecule ${ }^{-1} \mathrm{~s}^{-1}<$ xylene (7.4-14) $\times 10^{-12} \mathrm{~cm}^{3}$ molecule ${ }^{-1} \mathrm{~s}^{-1}<\mathrm{TMB}$ 31 ) $\times 10^{-12} \mathrm{~cm}^{3}$ molecule $\mathrm{s}^{-1}$ at $304 \pm 1 \mathrm{~K}$ (Doyle et al., 1975; Anderson and Hites, 1996). Combining this with our results, it was solidly concluded that AHs with a lower number of substituents showed lower reactivity, which resulted in the formation of higher concentrated $\mathrm{O}_{3}$.

Furthermore, to figure out the formation mechanisms of $\mathrm{O}_{3}$ from direct $\mathrm{AH}$ oxidation, the corresponding volatile intermediates were also monitored. Toluene was taken as an example to illustrate the concentration variation of volatile intermediates. As Fig. 1b shows, with a decrease of toluene's concentration from 996 to $944.5 \mathrm{ppb}$, the concentrations of nine intermediates increased at different degrees. The concentrations of $m / z=45$ ( $m 45$, acetaldehyde), $m / z=47$
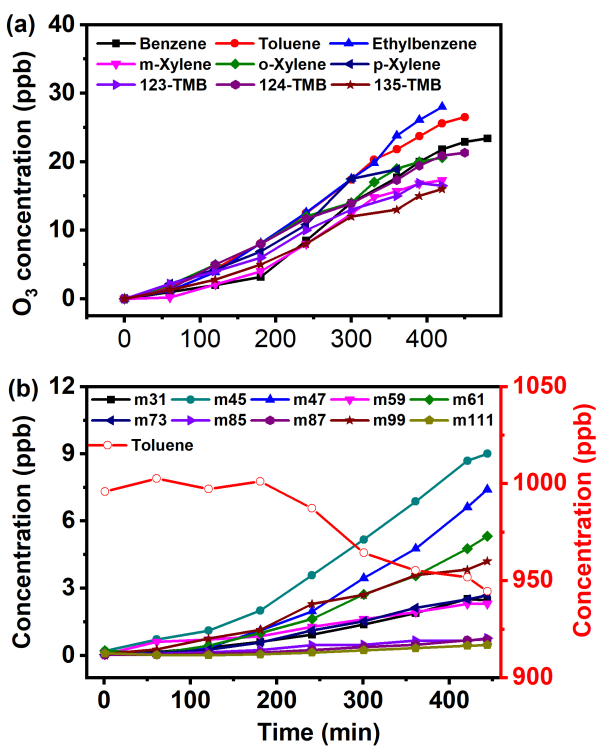

Figure 1. (a) $\mathrm{O}_{3}$ formation curve from $\mathrm{AH}$ photochemical oxidation (2110 ppb of benzene, $996 \mathrm{ppb}$ of toluene, $1060 \mathrm{ppb}$ of ethylbenzene, $889 \mathrm{ppb}$ of $m$-xylene, $1160 \mathrm{ppb}$ of $o$-xylene, $1040 \mathrm{ppb}$ of $p$-xylene, $824 \mathrm{ppb}$ of 123-TMB, $935 \mathrm{ppb}$ of 124-TMB, $913 \mathrm{ppb}$ of 135-TMB) without $\mathrm{NO}_{x}$. (b) The concentration variation of intermediates formed from $996 \mathrm{ppb}$ of toluene photochemical oxidation without $\mathrm{NO}_{x}$.

( $m 47$, formic acid), and $m / z=61$ ( $m 61$, acetic acid or glycolaldehyde) increased faster than others and peaked at 5-9 ppb within $450 \mathrm{~min}$, indicating easy oxidation of toluene to small molecular carbonyl products. The peak concentration of $m / z=99$ ( $m 99$, 3-methyl-2(5H)-furanone or 4-keto-2-pentenal) reached $4.2 \mathrm{ppb}$, while the production of $m / z=31$ ( $m 31$, formaldehyde), $m / z=59$ ( $m 59$, glyoxal), $m / z=73$ ( $m 73$, methylglyoxal) was at the same level (ca. $2.4 \mathrm{ppb}$ ). The concentrations of some intermediates including $m / z=85$ ( $m 85,2$-butenedial), $m / z=87$ ( $m 87$, butanedione), and $m / z=111$ ( $m 111$, hexa-2,4-dienedial) were lower than $0.8 \mathrm{ppb}$ within $450 \mathrm{~min}$ reaction duration. Similar variation trends of volatile intermediates were observed for the other eight AHs (Fig. S1 in the Supplement).

It is worth mentioning that most of the above intermediates are well-known precursors of $\mathrm{O}_{3}$ and SOA ( $\mathrm{Li}$ et al., 2016; Ji et al., 2017; Nishino et al., 2010). However, the formation of SOA was not observed in this study. Two reasons might be involved. Since this study was carried out at low $\mathrm{RH}(<5 \%)$ and without seed particles, no SOA precursor oligomers existed. Furthermore, the concentrations of intermediates produced were too low to trigger the initial nucleation reaction and then generate SOA under low RH conditions. Therefore, SOA formation could not be observed in the $\mathrm{NO}_{x}$-free photochemical oxidation of these nine AHs. In general, tropospheric $\mathrm{O}_{3}$ is mainly from $\mathrm{NO}_{2}$ photolysis, and the existence of AHs could enhance $\mathrm{O}_{3}$ formation. However, with the absence of $\mathrm{NO}_{x}$ in this study, the low concen- 


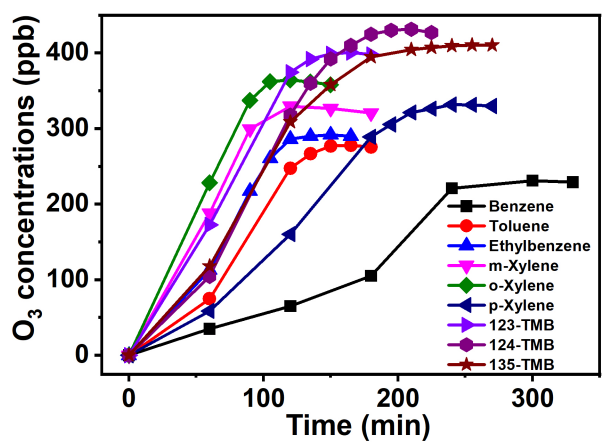

Figure 2. $\mathrm{O}_{3}$ formation curve from $\mathrm{AH}$ photochemical oxidation with the presence of $\mathrm{NO}_{x}$ (2000 ppb of benzene and $160.2 \mathrm{ppb}$ of $\mathrm{NO}_{x}, 1048 \mathrm{ppb}$ of toluene and $162.0 \mathrm{ppb}$ of $\mathrm{NO}_{x}, 1050 \mathrm{ppb}$ of ethylbenzene and $162.4 \mathrm{ppb}$ of $\mathrm{NO}_{x}, 889 \mathrm{ppb}$ of $m$-xylene and $172.1 \mathrm{ppb}$ of $\mathrm{NO}_{x}, 1052 \mathrm{ppb}$ of $o$-xylene and $159.8 \mathrm{ppb}$ of $\mathrm{NO}_{x}$, $1040 \mathrm{ppb}$ of $p$-xylene and $157.2 \mathrm{ppb}$ of $\mathrm{NO}_{x}, 956 \mathrm{ppb}$ of 123-TMB and $171.4 \mathrm{ppb}$ of $\mathrm{NO}_{x}, 1010 \mathrm{ppb}$ of 124-TMB and $169.5 \mathrm{ppb}$ of $\mathrm{NO}_{x}, 1040 \mathrm{ppb}$ of 135-TMB and 164.2 ppb of $\mathrm{NO}_{x}$ ).

trated $\mathrm{O}_{3}$ was observed from $\mathrm{AH}$ photochemical oxidation. The possible contributors of these $\mathrm{O}_{3}$ might be intermediates such as carbonyl compounds. In all, our results indicated that direct photochemical transformation of $\mathrm{AHs}$ to $\mathrm{O}_{3}$ actually occurred and should be taken into consideration in the atmospheric environment.

\subsection{Formation kinetics and mechanisms of $\mathrm{O}_{3}$ in the presence of $\mathrm{NO}_{x}$}

To further explore the role of $\mathrm{NO}_{x}$ in $\mathrm{O}_{3}$ formation during photochemical oxidation of AHs, about $160 \pm 10 \mathrm{ppb}$ of $\mathrm{NO}_{2}$ was added into the reactor. The concentration of $\mathrm{NO}_{2}$ was selected based on previous works (Luo et al., 2019; Chen et al., 2018). Under this condition, the generated $\mathrm{O}_{3}$ was found to significantly increase, and the $\mathrm{O}_{3}$ peak concentrations ranged from 230 to $440 \mathrm{ppb}$ within 100 to $250 \mathrm{~min}$ (Fig. 2). All these data were about 200-400 ppb higher than those obtained in the absence of $\mathrm{NO}_{x}$ (Fig. 1a), indicating the quick enhancement of $\mathrm{NO}_{x}$ to $\mathrm{O}_{3}$ formation. In this work, the added $\mathrm{NO}_{2}$ was firstly photolyzed under $360 \mathrm{~nm}$ light irradiation to form $\mathrm{NO}$ and $\mathrm{O}\left({ }^{3} \mathrm{P}\right)$ (Eq. 1). Then, the latter was oxidized to form $\mathrm{O}_{3}$ (Eq. 2), which further reacted with $\mathrm{NO}$ to form $\mathrm{NO}_{2}$ (Eq. 3). Meanwhile, AHs were photochemically oxidized to form $\mathrm{RO}_{2}$ and $\mathrm{HO}_{2}$, both of which then reacted with $\mathrm{NO}$ to form $\mathrm{NO}_{2}$ (Eqs. 4 and 5). Clearly, the presence of AHs could compete with $\mathrm{O}_{3}$ for the NO reaction and reduce the consumption of $\mathrm{O}_{3}$. The synergetic effect of direct $\mathrm{NO}_{2}$ conversion and $\mathrm{AH}$ competition reaction led to the boosting of the formation of $\mathrm{O}_{3}$ in the presence of both $\mathrm{AHs}$ and $\mathrm{NO}_{x}$.

$$
\begin{aligned}
& \mathrm{NO}_{2}+h v(\lambda=360 \mathrm{~nm}) \rightarrow \mathrm{NO}+\mathrm{O}\left({ }^{3} \mathrm{P}\right) \\
& \mathrm{O}\left({ }^{3} \mathrm{P}\right)+\mathrm{O}_{2} \rightarrow \mathrm{O}_{3} \\
& \mathrm{NO}+\mathrm{O}_{3} \rightarrow \mathrm{NO}_{2}
\end{aligned}
$$
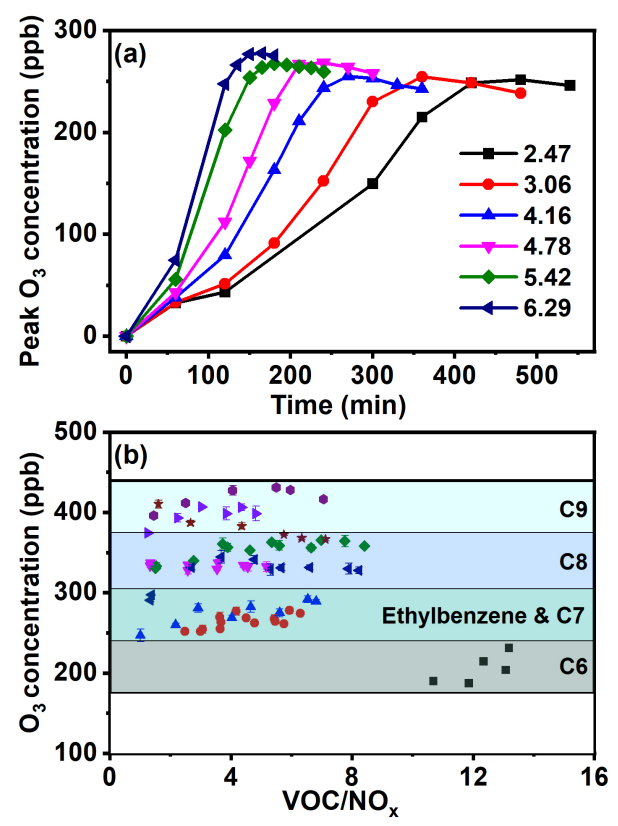

Figure 3. (a) $\mathrm{O}_{3}$ formation curve of toluene photochemical oxidation at different $\mathrm{VOC} / \mathrm{NO}_{x}$ ratios and (b) the changing trend of the peak $\mathrm{O}_{3}$ generated by photochemical oxidation of $\mathrm{AHs}$ at different VOC $/ \mathrm{NO}_{x}$ ratios (square: benzene; circle: toluene; upper triangle: ethylbenzene; lower triangle: $m$-xylene; diamond: $o$ xylene; left triangle: $p$-xylene; right triangle: 123-TMB; hexagon: 124-TMB; pentacle: 135-TMB).

$\mathrm{RO}_{2}+\mathrm{NO} \rightarrow \mathrm{NO}_{2}+\mathrm{RO}$
$\mathrm{HO}_{2}+\mathrm{NO} \rightarrow \mathrm{NO}_{2}+\cdot \mathrm{OH}$

Furthermore, the effect of $\mathrm{AH}$ content on the $\mathrm{O}_{3}$ formation in the presence of $\mathrm{NO}_{x}$ (e.g., $\mathrm{VOC} / \mathrm{NO}_{x}$ ratio) was investigated. Here, the concentration of $\mathrm{NO}_{x}$ was maintained constantly and that of $\mathrm{AH}$ was gradually increased. For toluene (Fig. 3a), $\mathrm{O}_{3}$ peak concentration of $250 \mathrm{ppb}$ was achieved after reaction for 420 min under a $\mathrm{VOC} / \mathrm{NO}_{x}$ ratio of 2.47 . When increasing the $\mathrm{VOC} / \mathrm{NO}_{x}$ ratio to 6.29 , the time needed to achieve a higher peak $\mathrm{O}_{3}$ concentration of $280 \mathrm{ppb}$ was shortened to $150 \mathrm{~min}$. All these data confirmed that $\mathrm{O}_{3}$ formation rate and concentration were both accelerated with increased AH concentration. Similar results of shorter reaction time leading to higher $\mathrm{O}_{3}$ concentration were observed for the rest of the AHs (Fig. S2). Increasing AH concentration would result in the enhanced formation of $\mathrm{RO}_{2}$ and $\mathrm{HO}_{2}$, both of which reacted with $\mathrm{NO}$ to save the $\mathrm{O}_{3}$ consumption. Meanwhile, the photolysis of $\mathrm{NO}_{2}$ to form $\mathrm{NO}$ and then $\mathrm{O}_{3}$ was also accelerated. Both of these reasons were responsible for the fast-enhanced formation of $\mathrm{O}_{3}$ with the increased $\mathrm{AH}$ concentration in the $\mathrm{VOC} / \mathrm{NO}_{x}$ ratio.

To study the effect of $\mathrm{AH}$ substituents on $\mathrm{O}_{3}$ formation, the $\mathrm{O}_{3}$ peak concentrations of nine $\mathrm{AHs}$ obtained at the same VOC $/ \mathrm{NO}_{x}$ ratio were compared. As Fig. 3b shows, the $\mathrm{O}_{3}$ peak concentrations of nine AHs followed the or- 
der of TMB (366.4-431.2 ppb) > xylene (290.6-365.7 ppb) $>$ toluene and ethylbenzene $(246.7-291.7 \mathrm{ppb})>$ benzene (187.3-231.2 ppb). Clearly, the $\mathrm{O}_{3}$ peak value was positively correlated with the number of AH substituents, suggesting AHs with more substituents possessed higher $\mathrm{O}_{3}$ production potential at the same $\mathrm{VOC} / \mathrm{NO}_{x}$ ratio. In previous studies, $\mathrm{O}_{3}$ concentrations from $\mathrm{AH}$ oxidation with the presence of $\mathrm{NO}_{x}$ were reported as follows: $160-300 \mathrm{ppb}$ for toluene, $400 \mathrm{ppb}$ for $m$-xylene, and 340-470 ppb for 123-TMB (Luo et al., 2019; Li et al., 2018; Xu et al., 2015). However, these studies only focused on one or several AHs, and the relationship between $\mathrm{AH}$ substituents and $\mathrm{O}_{3}$ formation was still not understood. Meanwhile, the $\mathrm{VOC} / \mathrm{NO}_{x}$ ratio ranging from 1.0 to 13.0 was selected for its effect on $\mathrm{O}_{3}$ formation. The range of $\mathrm{VOC} / \mathrm{NO}_{x}$ ratio in the above research studies was close to that in our study (Table S2). Then, our results of $\mathrm{O}_{3}$ concentration were comparable to those in the previous studies under a similar range of the $\mathrm{VOC} / \mathrm{NO}_{x}$ ratio. Furthermore, the results obtained in this study clearly confirmed that increasing the substituent number of AHs correspondingly increased $\mathrm{O}_{3}$ concentration. It was also noticed that the $\mathrm{O}_{3}$ peak concentrations of xylene or TMB isomers were in the same range, suggesting the negligible effect of substituent position of $\mathrm{AHs}$ on their $\mathrm{O}_{3}$ formation.

\subsection{Accelerated formation of SOA in the presence of $\mathrm{NO}_{x}$}

Besides $\mathrm{O}_{3}$, the effect of $\mathrm{AH}$ concentration on the formation kinetics of SOA with the presence of $\mathrm{NO}_{x}$ was also investigated. As Fig. 4 shows, from the photochemical oxidation of toluene, the peak number concentration of SOA increased from $2.0 \times 10^{4}$ to $5.5 \times 10^{4}$ particle $\mathrm{cm}^{-3}$ with an increase of the $\mathrm{VOC} / \mathrm{NO}_{x}$ ratio from 2.37 to 5.58. The time to achieve the above concentration was shortened from 250 to $120 \mathrm{~min}$, while the median particle size range also increased from 300-400 to $400-500 \mathrm{~nm}$. Similar results of shorter time leading to higher concentration and larger particle size for SOA were observed for the other eight AHs with the increasing $\mathrm{VOC} / \mathrm{NO}_{x}$ ratio (Figs. S3-S10).

Previous studies reported the enhanced SOA yield with increased $\mathrm{NO}_{x}$ concentration (Zhao et al., 2018; Hurley et al., 2001; Song et al., 2007; Sarrafzadeh et al., 2016). This was because $\mathrm{NO}_{x}$ mainly influenced the distribution of oxidation products by affecting the $\mathrm{RO}_{2}$ reaction equilibrium, where $\mathrm{RO}_{2}$ easily converted to low-volatility $\mathrm{ROOH}$ or ROOR and thus resulted in the nucleation of new particles (Sarrafzadeh et al., 2016). However, in this study, we kept the $\mathrm{NO}_{x}$ concentration unchanged and modified the initial concentration of AHs. The increased $\mathrm{AHs}$ could lead to promoted $\mathrm{RO}_{2}$ formation, resulting in more low-volatility products' formation. The accumulation of low-volatility products promoted the nucleation of particulate matter and finally increased the yield of SOA.
The particle number and mass concentrations of SOA generated from nine AHs were further compared to evaluate the effect of AH substituents on the SOA formation. The particle number concentration of SOA was obtained at the endpoint of each reaction. With the increase of substituent number, the number concentration of SOA decreased (e.g., from $6.9 \times 10^{3}$ particle $\mathrm{m}^{-3}$ for 135 -TMB to $7.8 \times 10^{4}$ particle $\mathrm{m}^{-3}$ for toluene) (Fig. 5a). With the progress of the reaction, the mass concentration of SOA increased, and the increase of substituent number shortened the time achieving the peak mass concentration (Fig. 5b). These results revealed that the increase of substituent number of AHs increased SOA mass concentration but decreased its particle number. AHs with different substituent position also showed different SOA formation characteristics. For xylene, the peak mass concentration of $o$-xylene $\left(88.6 \mu \mathrm{g} \mathrm{m}^{-3}\right)$ was higher than that of $m$-xylene and $p$-xylene, while the peak mass concentration of $123-\mathrm{TMB}\left(82.0 \mu \mathrm{g} \mathrm{m}^{-3}\right)$ was significantly higher than that of 124-TMB $\left(31.8 \mu \mathrm{g} \mathrm{m}^{-3}\right)$ and 135 TMB $\left(27.6 \mu \mathrm{g} \mathrm{m}^{-3}\right)$ (Fig. 5b). These phenomena indicated that xylene and TMB with ortho-methyl substituents facilitated SOA formation. Further, the ortho-methyl group of isomers (e.g., $o$-xylene, 123-TMB) could more thoroughly be oxidized, producing more particles (Sato et al., 2010).

It has also been reported that seed particles (e.g., $\mathrm{NaCl}$ ) and highly relative humidity (up to $90 \%$ ) can significantly increase the yield of SOA (Wang et al., 2016; Luo et al., 2019; Jia and $\mathrm{Xu}, 2018$ ). However, in this study, the maximum SOA yield of $25 \%$ (Fig. S11) was produced with increasing $\mathrm{AH}$ concentration, which was consistent with that from previous research studies (Sato et al., 2012; Li et al., 2016; Song et al., 2007; Odum et al., 1997). Further considering the oxidation conditions of low RH (less than $5 \%$ ) and seedless particles in this study, our results indicated that $\mathrm{AH}$ concentration should also be paid much attention in relation to SOA formation, although the addition of $\mathrm{NO}_{x}$, seed particles, and high RH are also all very important.

To further investigate the effect of $\mathrm{AH}$ substituents on SOA yield, a two-product semi-empirical model was employed. As Fig. S12 shows, the model fitted the SOA yield of nine AHs well, and the corresponding fitting parameters are listed in Table 1. Similarly, high-volatility components were assumed from the photochemical oxidation of AHs and the same $K_{\mathrm{om}, 2}$ of $0.005 \mathrm{~m}^{3} \mu \mathrm{g}^{-1}$ was assigned. As seen from the table, benzene $\left(0.242 \mathrm{~m}^{3} \mu \mathrm{g}^{-1}\right)$, toluene $\left(0.162 \mathrm{~m}^{3} \mu \mathrm{g}^{-1}\right)$, and ethylbenzene $\left(0.422 \mathrm{~m}^{3} \mu \mathrm{g}^{-1}\right)$ showed higher $\alpha_{2}$ than that of xylenes (e.g., $0.086 \mathrm{~m}^{3} \mu \mathrm{g}^{-1}$ for $m$ xylene) and TMBs (e.g., $0.082 \mathrm{~m}^{3} \mu^{-1}$ for $123-\mathrm{TMB}$ ), indicating the production of more high-volatility products from AHs with a lower number of substituents. Meanwhile, benzene $\left(0.022 \mathrm{~m}^{3} \mu \mathrm{g}^{-1}\right)$, toluene $\left(0.027 \mathrm{~m}^{3} \mu \mathrm{g}^{-1}\right)$, and ethylbenzene $\left(0.023 \mathrm{~m}^{3} \mu \mathrm{g}^{-1}\right)$ displayed lower $K_{\mathrm{om}, 1}$ in comparison with xylenes (e.g., $0.074 \mathrm{~m}^{3} \mu \mathrm{g}^{-1}$ for $p$-xylene) and TMBs (e.g., $0.085 \mathrm{~m}^{3} \mu \mathrm{g}^{-1}$ for $135-\mathrm{TMB}$ ), and the corresponding $\alpha_{1}$ decreased with increasing substituent number. 

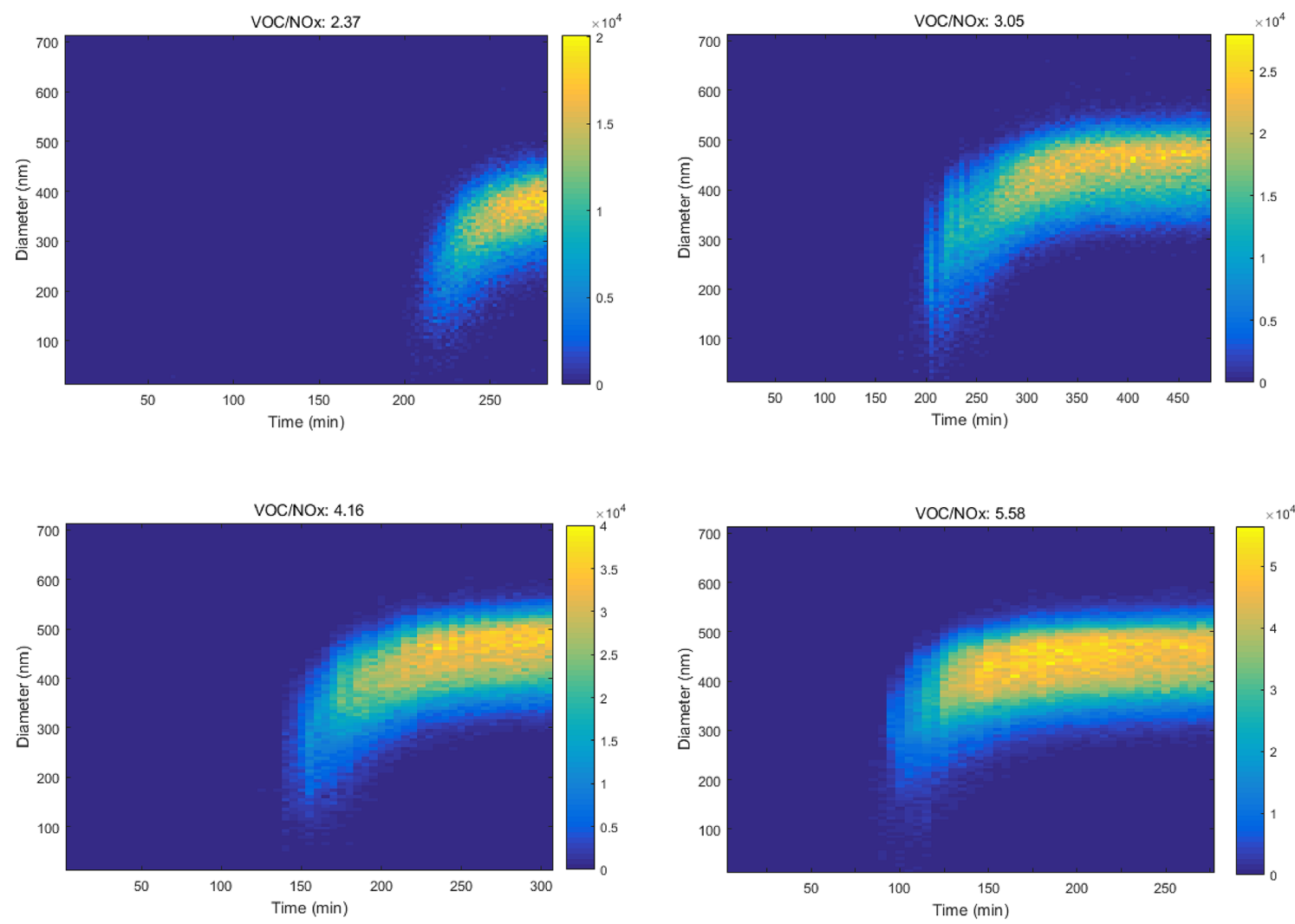

Figure 4. Nanoparticle distribution from toluene photochemical oxidation varied with time at different $\mathrm{VOC}_{\text {/ }} \mathrm{NO}_{x}$ ratios (the initial concentrations of $\mathrm{NO}_{x}$ were in the range of 158.2 to $179.7 \mathrm{ppb}$ ).

All these results demonstrated that the increase of substituent number on the phenyl ring inhibited the generation of lowvolatility products, thus reducing the generation of SOA particles and finally leading to the decrease of SOA yield. The results also indicated that the oxidation degree became lower and lower for AHs with increased substituent number, since the oxidation of methyl carbon was more difficult than that of carbon of the phenyl ring. Li et al. (2016) reported a similar phenomenon previously, which is consistent with our results. However, they did not further investigate the relationship of isomer AHs with the SOA yield.

In the present study, SOA yield of $o$-xylene was found higher than that of $m$-xylene and $p$-xylene, consistent with the SOA number and mass results. The fitting results showed that the $K_{\mathrm{om}, 1}$ of $o$-xylene $\left(0.024 \mathrm{~m}^{3} \mu \mathrm{g}^{-1}\right)$ was much lower than that of $m$-xylene $\left(0.057 \mathrm{~m}^{3} \mu \mathrm{g}^{-1}\right)$ and $p$ xylene $\left(0.074 \mathrm{~m}^{3} \mu \mathrm{g}^{-1}\right)$, indicating the production of more low-volatility products from $o$-xylene. Similarly, 123-TMB showed the highest SOA yield and lowest $K_{\text {om,1 }}$ among three TMBs. These results further confirmed that AHs with an ortho-methyl substituent favored the yield of SOA. This might be because these AHs were more susceptible to being oxidized and forming ring-opening products and finally producing more $\mathrm{RO}_{2}$ than other isomers. Some previous studies have also obtained results consistent with this (Zhou et al.,
Table 1. Fitting yield curve parameters of two-product semiempirical models.

\begin{tabular}{lcccc}
\hline AHs & $\alpha_{1}$ & $\begin{array}{c}K_{\mathrm{om}, 1} \\
\left(\mathrm{~m}^{3} \mu \mathrm{g}^{-1}\right)\end{array}$ & $\alpha_{2}$ & $\begin{array}{c}K_{\mathrm{om}, 2} \\
\left(\mathrm{~m}^{3} \mu \mathrm{g}^{-1}\right)\end{array}$ \\
\hline Benzene & 0.341 & 0.022 & 0.242 & 0.005 \\
Toluene & 0.157 & 0.027 & 0.162 & 0.005 \\
Ethylbenzene & 0.285 & 0.023 & 0.422 & 0.005 \\
m-Xylene & 0.103 & 0.057 & 0.086 & 0.005 \\
$o$-Xylene & 0.345 & 0.024 & 0.017 & 0.005 \\
p-Xylene & 0.085 & 0.074 & 0.057 & 0.005 \\
123-TMB & 0.114 & 0.025 & 0.082 & 0.005 \\
124-TMB & 0.068 & 0.075 & 0.080 & 0.005 \\
135-TMB & 0.080 & 0.085 & 0.032 & 0.005 \\
\hline
\end{tabular}

2011; Song et al., 2007). In addition, ethylbenzene was also isomeric to xylene, and its SOA yield was higher than that of xylenes. Recent studies have found that the SOA yield during the oxidation of alkanes and alkenes by $\cdot \mathrm{OH}$ increased with the carbon chain length (Lim and Ziemann, 2009; Tkacik et al., 2012). Clearly, the length of carbon chain also affected the oxidation degree of AHs. Then, the longer ethyl group led to a higher degree of photochemical oxidation for ethyl- 


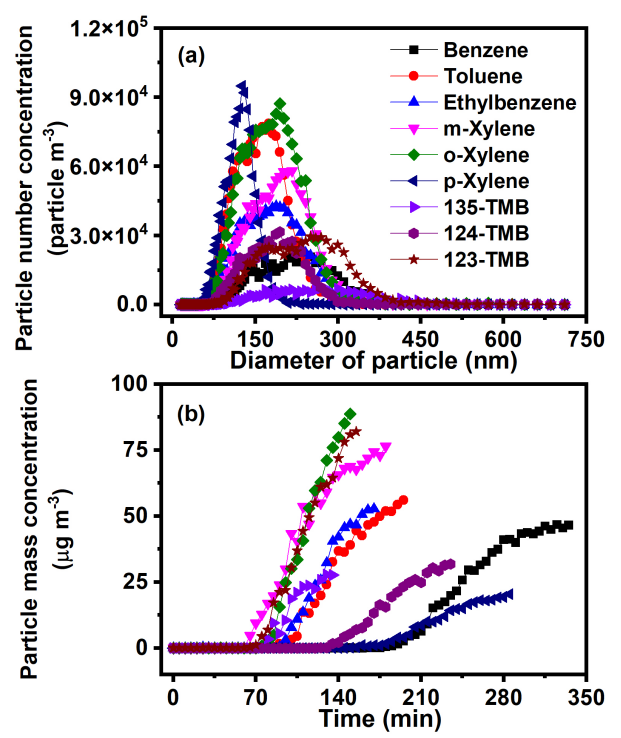

Figure 5. (a) Number concentration and (b) mass concentration of SOA produced from $\mathrm{AH}$ photochemical oxidation with the presence of $\mathrm{NO}_{x}\left(2000 \mathrm{ppb}\right.$ of benzene and $160.2 \mathrm{ppb}$ of $\mathrm{NO}_{x}, 1048 \mathrm{ppb}$ of toluene and $162.0 \mathrm{ppb}$ of $\mathrm{NO}_{x}, 1050 \mathrm{ppb}$ of ethylbenzene and $162.4 \mathrm{ppb}$ of $\mathrm{NO}_{x}, 889 \mathrm{ppb}$ of $m$-xylene and $172.1 \mathrm{ppb}$ of $\mathrm{NO}_{x}$, $1052 \mathrm{ppb}$ of $o$-xylene and $159.8 \mathrm{ppb}$ of $\mathrm{NO}_{x}, 1040 \mathrm{ppb}$ of $p$-xylene and 157.2 ppb of $\mathrm{NO}_{x}, 956 \mathrm{ppb}$ of 123-TMB and 171.4 ppb of $\mathrm{NO}_{x}$, $1010 \mathrm{ppb}$ of $124-\mathrm{TMB}$ and $169.5 \mathrm{ppb}$ of $\mathrm{NO}_{x}, 1040 \mathrm{ppb}$ of $135-$ TMB and $164.2 \mathrm{ppb}$ of $\mathrm{NO}_{x}$ ).

benzene than xylenes, promoting the formation of more SOA precursors and finally higher SOA yield.

\subsection{Enhanced formation mechanisms of SOA with $\mathrm{NO}_{x}$}

In order to further reveal the enhanced formation mechanisms of SOA from the oxidation of AHs with the presence of $\mathrm{NO}_{x}$, the corresponding volatile intermediates were all identified and quantified comparably. As Fig. 6a shows, with a gradual decrease of toluene concentration, the concentrations of small molecule carbonyl products, such as $m 31$, $m 45, m 47$, and $m 61$, quickly increased to $16.0,45.3,31.0$, and $17.0 \mathrm{ppb}$ within $200 \mathrm{~min}$. Acetaldehyde showed the highest concentration, which was by far higher than that obtained without $\mathrm{NO}_{x}(9 \mathrm{ppb})$. The ones that followed were $m 85$, $m 87$, and $m 111$, with a peak concentration below $2.8 \mathrm{ppb}$. The increase of concentration of $m 59, m 73$, and $m 99$ began to slow down after $120 \mathrm{~min}$, and this trend was consistent with the trend of SOA formation (Fig. 5b). A similar variation trend of volatile intermediates for other AHs was also measured (Fig. S13). All these results demonstrated that there was a specific window period, and the intermediates in the gaseous phase were transformed into the particulate phase. The significant increase of SOA occurred after breaking through the window period.

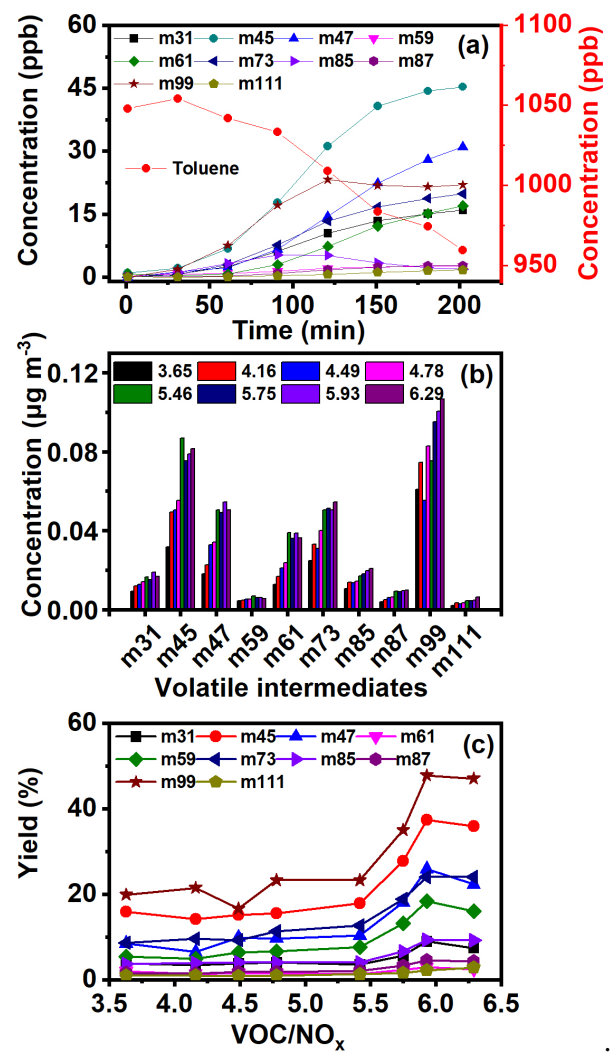

Figure 6. (a) Intermediate concentration variation along with the reaction time under $1048 \mathrm{ppb}$ of toluene and $162.0 \mathrm{ppb}$ of $\mathrm{NO}_{x}$, (b) intermediate concentration, and (c) yield from toluene photochemical oxidation with the increase of the $\mathrm{VOC} / \mathrm{NO}_{x}$ ratio

Further comparison of volatile intermediates during photochemical oxidation of $\mathrm{AHs}$ with different $\mathrm{VOC} / \mathrm{NO}_{x}$ ratios was also carried out. For toluene oxidation (Fig. 6b), the concentrations of all intermediates increased with the increase of the $\mathrm{VOC} / \mathrm{NO}_{x}$ ratio. The carbonyl intermediates such as $m 59$ and $m 73$ were believed to play an important role in the photochemical oxidation of AHs to form SOA ( $\mathrm{Li}$ et al., 2016; Ji et al., 2017; Nishino et al., 2010). Bloss et al. (2005b) also found glyoxal and methylglyoxal produced from toluene photochemical oxidation to be the main precursor of SOA. In previous studies, maximum yields of glyoxal and methylglyoxal of $20 \%$ and $17 \%$ were obtained during toluene photochemical oxidation (Baltaretu et al., 2009; Volkamer et al., 2001; Nishino et al., 2010), which were lower than those of the present study (24\% in Fig. 6c). Meanwhile, the yields of glyoxal and methylglyoxal during photochemical oxidation of toluene, xylenes, and TMBs increased with increasing AH concentration. Therefore, the increase of $\mathrm{AH}$ content in the reaction system promoted the photochemical oxidation of AHs to produce more volatile carbonyl intermediates, finally leading to higher SOA yield in this study. Moreover, the yield of $m 59$ and $m 73$ from benzene photochemical oxidation was found to be the lowest among all 


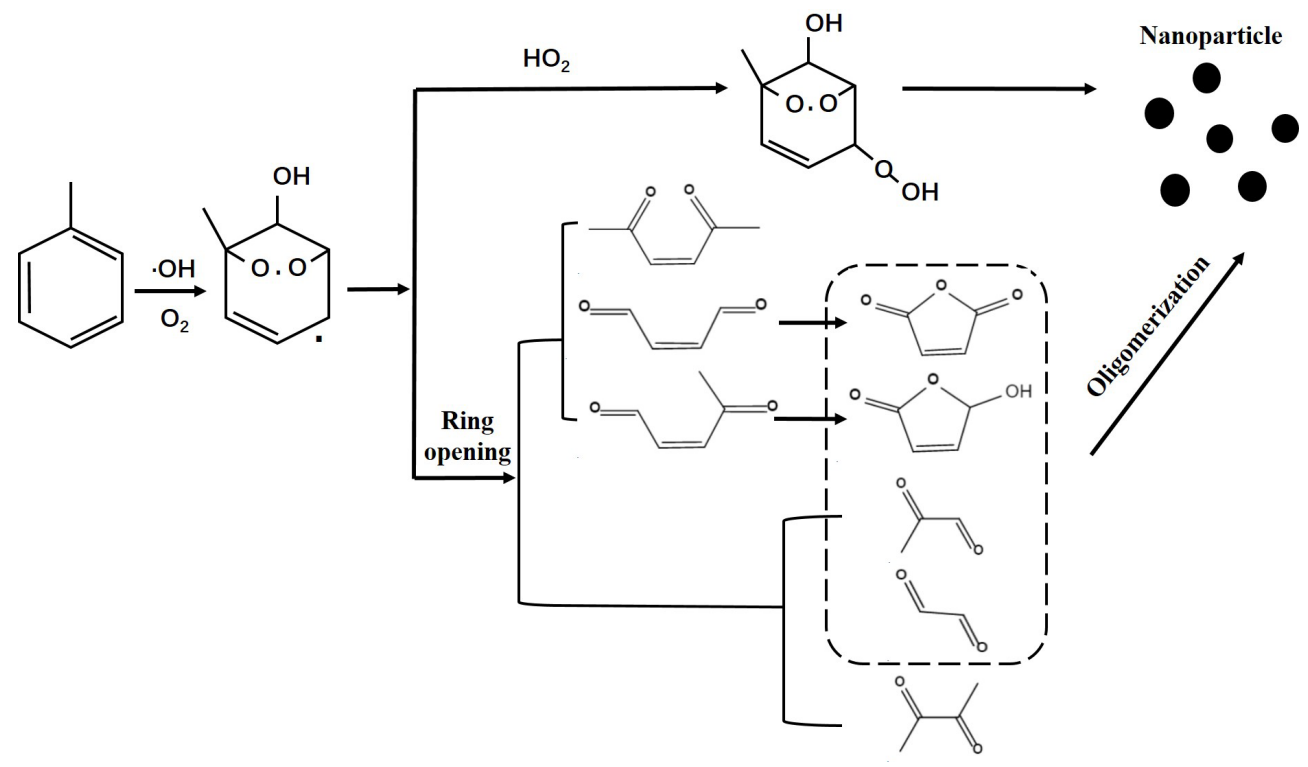

Figure 7. The possible photochemical oxidation mechanism of toluene to SOA formation.

AHs (Figs. 6b, c and S14-S22), indicating that the presence of the branch chain on the phenyl ring did not favor the production of unsaturated carbonyl compounds. This was because the increasing methyl group number of AHs weakened their oxidation reactivity, resulting in the inhibition of the ring-opening reaction ( $\mathrm{Li}$ et al., 2016). Further, the formation of glyoxal and methylglyoxal from $\mathrm{RO}_{2}$ was also subsequently suppressed. Furthermore, the yields of $m 85$ from AHs containing an ortho-methyl group (e.g., $o$-xylene, 123TMB, and 124-TMB) were found higher to be than those of their isomers, due to ortho-methyl groups of the phenyl ring preferring the ring-opening reaction and the subsequent generation of ketone products (Li et al., 2016).

Based on the above results, the possible photochemical oxidation mechanism from $\mathrm{AH}$ to SOA was proposed. Toluene was selected as an example. As Fig. 7 shows, the phenyl ring of toluene firstly reacted with ${ }^{\bullet} \mathrm{OH}$ to produce cresol (Ziemann, 2011; Atkinson, 2007) and then further oxidized to form an intermediate, which could cause a ring-opening reaction or react with $\mathrm{HO}_{2}$ radicals to form bicyclic peroxide compounds. The latter has been suggested as an important SOA precursor of AH photochemical oxidation (Song et al., 2005; Wyche et al., 2009; Nakao et al., 2011; Johnson et al., 2005). The ring-opening intermediates were consisted of saturated and unsaturated dicarbonyl compounds (Jang and Kamens, 2001; Birdsall and Elrod, 2011). However, the possibility of these dicarbonyl intermediates directly partitioning into the particulate phase was very small (Jang and Kamens, 2001), but they could oligomerize to form lowvolatility compounds (Forstner et al., 1997; Jang and Kamens, 2001). The oligomerization was an important pathway for SOA formation from AH photochemical oxidation (Sato et al., 2012; Li et al., 2016; Hu et al., 2007). In our study, the detection of $m 85$ and $m 99$ proved the formation of ringopening products. These unsaturated 1,4-dicarbonyls were observed to form small cyclic furanone compounds (Jang and Kamens, 2001; Bloss et al., 2005b). Therefore, the ringopening products with saturated or unsaturated dicarbonyl groups finally transformed into SOA through the oligomerization process.

As mentioned above, with the increase of the substituent number on AHs, the yield of SOA decreased. The enhanced ring-opening products and restrained oligomerization reactions by the increased methyl group number were supposed to be the main cause. The methyl group was found to stabilize the ring-opening radicals (Ziemann, 2011). When the phenyl ring contained a methyl group, the oxidation pathway was prone to ring-opening. The concentrations of $m 87$ and $m 111$ increased with the increase of the methyl group number (Fig. S23), meaning that these two intermediates were dominant in the ring-opening products. However, they could not oligomerize to further partition into SOA formation (Fig. 7). Both non-cyclic dicarbonyls and cyclic compounds formed by unsaturated dicarbonyls were deemed to have a small probability of oligomerizing (Li et al., 2016; Kalberer et al., 2004). In previous study, no $m 85$ and $m 111$ were detected in particulate-phase SOA under $300 \pm 1 \mathrm{~K}$ and dry conditions $(\mathrm{RH}<0.1 \%)$ in the absence of inorganic seed aerosol (Li et al., 2016). However, $m 85$ was measured in the gas phase of this study, indicating that it was not the precursor of SOA for the oligomerization reaction. The presence of methyl groups would inhibit the oligomerization to prevent the formation of ring compounds by unsaturated dicarbonyl groups and finally decrease SOA formation. 


\section{Conclusions}

In this study, no SOA formation was observed from the direct photochemical oxidation of AHs, while a small amount of $\mathrm{O}_{3}$ was produced without $\mathrm{NO}_{x}$ addition. The presence of $\mathrm{NO}_{x}$ significantly increased the production of $\mathrm{O}_{3}$ and $\mathrm{SOA}$, due to the synergetic effect of accelerated $\mathrm{NO}_{2}$ conversion and $\mathrm{AH}$ reaction with $\mathrm{NO}$ as well as enhanced formation of volatile intermediates. Further increased formation of both $\mathrm{O}_{3}$ and SOA was observed by promoted $\mathrm{AH}$ concentration. In addition, an increase of $\mathrm{AH}$ substituent number could enhance $\mathrm{O}_{3}$ formation but decrease SOA yield. The ortho-methyl-groupsubstituted AHs exhibited a higher SOA yield. The preferential formation of variation of dicarbonyl intermediates and restrained oligomerization reaction were responsible for the above differences. These results showed more clear understanding of the effect of $\mathrm{NO}_{x}$ and organic molecule structures on photochemical oxidation of AHs to form $\mathrm{O}_{3}$ and SOA, which could provide a solid experimental basis for studying the transformation of AHs to secondary pollutants in the real atmospheric environment.

Code availability. The code used in this study is available upon request from Hao Luo (luohao6@foxmail.com).

Data availability. The data that support the results are available from the corresponding author upon request.

Supplement. The supplement related to this article is available online at: https://doi.org/10.5194/acp-21-7567-2021-supplement.

Author contributions. TA designed research. HL and JC conducted experiments. HL, JC, and GL analyzed data. HL prepared the manuscript with contributions from all coauthors.

Competing interests. The authors declare that they have no conflict of interest.

Financial support. This research has been supported by the National Natural Science Foundation of China (grant nos. 42020104001 and 41731279), the Local Innovative and Research Team Project of Guangdong Pearl River Talents Program (2017BT01Z032), the Guangdong Provincial Key Research and Development Program (2019B110206002), and the National Key R\&D Program of China (2019YFC0214402).

Review statement. This paper was edited by Jianping Huang and reviewed by two anonymous referees.

\section{References}

An, T. C., Huang, Y., Li, G. Y., He, Z. G., Chen, J. Y., and Zhang, C. S.: Pollution profiles and health risk assessment of VOCs emitted during e-waste dismantling processes associated with different dismantling methods, Environ. Int., 73, 186-194, https://doi.org/10.1016/j.envint.2014.07.019, 2014.

Anderson, P. N. and Hites, R. A.: OH radical reactions: the major removal pathway for polychlorinated biphenyls from the atmosphere, Environ. Sci. Technol., 30, 1756-1763, 1996.

Aschmann, S. M., Arey, J., and Atkinson, R.: Rate constants for the reactions of $\mathrm{OH}$ radicals with 1,2,4,5-tetramethylbenzene, pentamethylbenzene, 2,4,5-trimethylbenzaldehyde, 2,4,5trimethylphenol, and 3-methyl-3-hexene-2,5-dione and products of $\mathrm{OH}+1,2,4,5$-tetramethylbenzene, J. Phys. Chem. A, 117, 2556-2568, https://doi.org/10.1021/jp400323n, 2013.

Atkinson, R.: Rate constants for the atmospheric reactions of alkoxy radicals: An updated estimation method, Atmos. Environ., 41, 8468-8485, https://doi.org/10.1016/j.atmosenv.2007.07.002, 2007.

Atkinson, R. and Arey, J.: Gas-phase tropospheric chemistry of biogenic volatile organic compounds: a review, Atmos. Environ., 37, 197-219, https://doi.org/10.1016/s1352-2310(03)00391-1, 2003.

Baltaretu, C. O., Lichtman, E. I., Hadler, A. B., and Elrod, M. J.: Primary atmospheric oxidation mechanism for toluene, J. Phys. Chem. A, 113, 221-230, 2009.

Birdsall, A. W. and Elrod, M. J.: Comprehensive NO-dependent study of the products of the oxidation of atmospherically relevant aromatic compounds, J. Phys. Chem. A, 115, 5397-5407, https://doi.org/10.1021/jp2010327, 2011.

Bloss, C., Wagner, V., Bonzanini, A., Jenkin, M. E., Wirtz, K., Martin-Reviejo, M., and Pilling, M. J.: Evaluation of detailed aromatic mechanisms (MCMv3 and MCMv3.1) against environmental chamber data, Atmos. Chem. Phys., 5, 623-639, https://doi.org/10.5194/acp-5-623-2005, 2005a.

Bloss, C., Wagner, V., Jenkin, M. E., Volkamer, R., Bloss, W. J., Lee, J. D., Heard, D. E., Wirtz, K., Martin-Reviejo, M., Rea, G., Wenger, J. C., and Pilling, M. J.: Development of a detailed chemical mechanism (MCMv3.1) for the atmospheric oxidation of aromatic hydrocarbons, Atmos. Chem. Phys., 5, 641-664, https://doi.org/10.5194/acp-5-641-2005, 2005b.

Borrás, E. and Tortajada-Genaro, L. A.: Secondary organic aerosol formation from the photo-oxidation of benzene, Atmos. Environ., 47, 154-163, https://doi.org/10.1016/j.atmosenv.2011.11.020, 2012.

Carter, W. P. L. and Heo, G.: Development of revised SAPRC aromatics mechanisms, Atmos. Environ., 77, 404-414, https://doi.org/10.1016/j.atmosenv.2013.05.021, 2013.

Chen, J. Y., He, Z. G., Ji, Y. M., Li, G. Y., An, T. C., and Choi, W. Y.: (OH)-O-center dot radicals determined photocatalytic degradation mechanisms of gaseous styrene in $\mathrm{TiO}_{2}$ system under $254 \mathrm{~nm}$ versus $185 \mathrm{~nm}$ irradiation: Combined experimental and theoretical studies, Appl. Catal. B-Environ., 257, 117912, https://doi.org/10.1016/J.Apcatb.2019.117912, 2019.

Chen, J. Y., Yi, J. J., Ji, Y. M., Zhao, B. C., Ji, Y. P., Li, G. Y., and An, T. C.: Enhanced H-abstraction contribution for oxidation of xylenes via mineral particles: Implications for particulate matter formation and human health, Environ. Res., 186, 109568, https://doi.org/10.1016/J.Envres.2020.109568, 2020. 
Chen, Y., Tong, S. R., Wang, J., Peng, C., Ge, M. F., Xie, X. F., and Sun, J.: Effect of titanium dioxide on secondary organic aerosol formation, Environ. Sci. Technol., 52, 11612-11620, https://doi.org/10.1021/acs.est.8b02466, 2018.

Cocker III, D. R., Mader, B. T., Kalberer, M., Flagan, R. C., and Seinfeld, J. H.: The effect of water on gas-particle partitioning of secondary organic aerosol: II. $m$-xylene and 1,3,5trimethylbenzene photooxidation systems, Atmos. Environ., 35, 6073-6085, 2001.

Doyle, G. J., Lloyd, A. C., Darnall, K. R., Winer, A. M., and Pitts Jr., J. N.: Gas phase kinetic study of relative rates of reaction of selected aromatic compounds with hydroxyl radicals in an environmental chamber, Environ. Sci. Technol., 9, 237-241, 1975.

Forstner, H. J. L., Flagan, R. C., and Seinfeld, J. H.: Secondary organic aerosol from the photooxidation of aromatic hydrocarbons: molecular composition, Environ. Sci. Technol., 31, 1345-1358, 1997.

Geng, F., Tie, X., Xu, J., Zhou, G., Peng, L., Gao, W., Tang, $\mathrm{X}$., and Zhao, C.: Characterizations of ozone, $\mathrm{NO}_{x}$, and VOCs measured in Shanghai, China, Atmos. Environ., 42, 6873-6883, https://doi.org/10.1016/j.atmosenv.2008.05.045, 2008.

Glasson, W. A. and Tuesday, C. S.: Hydrocarbon reactivities in the atmospheric photooxidation of nitric oxide, Environ. Sci. Technol., 4, 916-924, 1970.

Han, C., Liu, R., Luo, H., Li, G., Ma, S., Chen, J., and An, T.: Pollution profiles of volatile organic compounds from different urban functional areas in Guangzhou China based on GC/MS and PTR-TOF-MS: Atmospheric environmental implications, Atmos. Environ., 214, 116843, https://doi.org/10.1016/j.atmosenv.2019.116843, 2019.

He, Z. G., Li, G. Y., Chen, J. Y., Huang, Y., An, T. C., and Zhang, C. S.: Pollution characteristics and health risk assessment of volatile organic compounds emitted from different plastic solid waste recycling workshops, Environ. Int., 77, 85-94, https://doi.org/10.1016/j.envint.2015.01.004, 2015.

Henze, D. K., Seinfeld, J. H., Ng, N. L., Kroll, J. H., Fu, T.-M., Jacob, D. J., and Heald, C. L.: Global modeling of secondary organic aerosol formation from aromatic hydrocarbons: highvs. low-yield pathways, Atmos. Chem. Phys., 8, 2405-2420, https://doi.org/10.5194/acp-8-2405-2008, 2008.

Hu, D., Tolocka, M., Li, Q., and Kamens, R. M.: A kinetic mechanism for predicting secondary organic aerosol formation from toluene oxidation in the presence of $\mathrm{NO}_{x}$ and natural sunlight, Atmos. Environ., 41, 6478-6496, https://doi.org/10.1016/j.atmosenv.2007.04.025, 2007.

Hu, L., Millet, D. B., Baasandorj, M., Griffis, T. J., Travis, K. R., Tessum, C. W., Marshall, J. D., Reinhart, W. F., Mikoviny, T., Müller, M., Wisthaler, A., Graus, M., Warneke, C., and de Gouw, J.: Emissions of $\mathrm{C}_{6}-\mathrm{C}_{8}$ aromatic compounds in the United States: Constraints from tall tower and aircraft measurements, J. Geophys. Res.-Atmos., 120, 826-842, https://doi.org/10.1002/2014JD022627, 2015.

Hurley, M. D., Sokolov, O., Wallington, T. J., Takekawa, H., Karasawa, M., Klotz, B., Barnes, I., and Becker, K. H.: Organic aerosol formation during the atmospheric degradation of toluene, Environ. Sci. Technol., 35, 1358-1366, https://doi.org/10.1021/es0013733, 2001.

Jang, M. and Kamens, R. M.: Characterization of Secondary Aerosol from the Photooxidation of Toluene in the Presence of $\mathrm{NO}_{x}$ and 1-Propene, Environ. Sci. Technol., 35, 3626-3639, https://doi.org/10.1021/es010676+, 2001.

Ji, Y., Zhao, J., Terazono, H., Misawa, K., Levitt, N. P., Li, Y., Lin, Y., Peng, J., Wang, Y., Duan, L., Pan, B., Zhang, F., Feng, X., An, T., Marrero-Ortiz, W., Secrest, J., Zhang, A. L., Shibuya, K., Molina, M. J., and Zhang, R.: Reassessing the atmospheric oxidation mechanism of toluene, P. Natl. Acad. Sci. USA, 114, 8169-8174, https://doi.org/10.1073/pnas.1705463114, 2017.

Ji, Y., Zheng, J., Qin, D., Li, Y., Gao, Y., Yao, M., Chen, X., Li, G., An, T., and Zhang, R.: OH-Initiated Oxidation of Acetylacetone: Implications for Ozone and Secondary Organic Aerosol Formation, Environ. Sci. Technol., 52, 11169-11177, https://doi.org/10.1021/acs.est.8b03972, 2018.

Jia, L. and $\mathrm{Xu}, \mathrm{Y}$.: Different roles of water in secondary organic aerosol formation from toluene and isoprene, Atmos. Chem. Phys., 18, 8137-8154, https://doi.org/10.5194/acp-188137-2018, 2018.

Johnson, D., Jenkin, M. E., Wirtz, K., and Martin-Reviejo, M.: Simulating the formation of secondary organic aerosol from the photooxidation of toluene, Environ. Chem., 2, 35-48, https://doi.org/10.1071/en04069, 2005.

Kalberer, M., Paulsen, D., Sax, M., Steinbacher, M., Dommen, J., Prevot, A. S. H., Fisseha, R., Weingartner, E., Frankevich, V., and Zenobi, R.: Identification of polymers as major components of atmospheric organic aerosols, Science, 303, 1659-1662, 2004.

Lane, T. E., Donahue, N. M., and Pandis, S. N.: Simulating secondary organic aerosol formation using the volatility basisset approach in a chemical transport model, Atmos. Environ., 42, 7439-7451, https://doi.org/10.1016/j.atmosenv.2008.06.026, 2008.

Li, K., Chen, L., White, S. J., Yu, H., Wu, X., Gao, X., Azzi, M., and Cen, K.: Smog chamber study of the role of $\mathrm{NH}_{3}$ in new particle formation from photo-oxidation of aromatic hydrocarbons, Sci. Total Environ., 619-620, 927-937, https://doi.org/10.1016/j.scitotenv.2017.11.180, 2018.

Li, L., Tang, P., Nakao, S., Chen, C.-L., and Cocker III, D. R.: Role of methyl group number on SOA formation from monocyclic aromatic hydrocarbons photooxidation under low-NO ${ }_{x}$ conditions, Atmos. Chem. Phys., 16, 2255-2272, https://doi.org/10.5194/acp-16-2255-2016, 2016.

Li, Y., Lau, A. K. H., Fung, J. C. H., Zheng, J., and Liu, S.: Importance of $\mathrm{NO}_{x}$ control for peak ozone reduction in the Pearl River Delta region, J. Geophys. Res.-Atmos., 118, 9428-9443, https://doi.org/10.1002/jgrd.50659, 2013.

Lim, Y. B. and Ziemann, P. J.: Effects of molecular structure on aerosol yields from $\mathrm{OH}$ radical-initiated reactions of linear, branched, and cyclic alkanes in the presence of $\mathrm{NO}_{x}$, Environ. Sci. Technol., 43, 2328-2334, https://doi.org/10.1021/es803389s, 2009.

Lindinger, W., Hansel, A., and Jordan, A.: Proton-transfer-reaction mass spectrometry (PTR-MS): on-line monitoring of volatile organic compounds at pptv levels, Chem. Soc. Rev., 27, 347-354, 1998.

Luo, H., Jia, L., Wan, Q., An, T., and Wang, Y.: Role of liquid water in the formation of $\mathrm{O}_{3}$ and SOA particles from 1,2,3-trimethylbenzene, Atmos. Environ., 217, 116955, https://doi.org/10.1016/j.atmosenv.2019.116955, 2019.

Luo, H., Li, G., Chen, J., Ma, S., Wang, Y., and An, T.: Spatial and temporal distribution characteristics and ozone forma- 
tion potentials of volatile organic compounds from three typical functional areas in China, Environ. Res., 183, 109141, https://doi.org/10.1016/j.envres.2020.109141, 2020a.

Luo, H., Li, G., Chen, J., Wang, Y., and An, T.: Reactor characterization and primary application of a state of art dual-reactor chamber in the investigation of atmospheric photochemical processes, J. Environ. Sci., 98, 161-168, 2020b.

Metzger, A., Dommen, J., Gaeggeler, K., Duplissy, J., Prevot, A. S. H., Kleffmann, J., Elshorbany, Y., Wisthaler, A., and Baltensperger, U.: Evaluation of 1,3,5 trimethylbenzene degradation in the detailed tropospheric chemistry mechanism, MCMv3.1, using environmental chamber data, Atmos. Chem. Phys., 8, 6453-6468, https://doi.org/10.5194/acp-8-6453-2008, 2008.

Nakao, S., Clark, C., Tang, P., Sato, K., and Cocker III, D.: Secondary organic aerosol formation from phenolic compounds in the absence of $\mathrm{NO}_{x}$, Atmos. Chem. Phys., 11, 10649-10660, https://doi.org/10.5194/acp-11-10649-2011, 2011.

Nishino, N., Arey, J., and Atkinson, R.: Formation yields of glyoxal and methylglyoxal from the gas-phase $\mathrm{OH}$ radical-initiated reactions of toluene, xylenes, and trimethylbenzenes as a function of $\mathrm{NO}_{2}$ concentration, J. Phys. Chem. A, 114, 10140-10147, 2010.

Odum, J. R., Hoffmann, T., Bowman, F., Collins, D., Flagan, R. C., and Seinfeld, J. H.: Gas/particle partitioning and secondary organic aerosol yields, Environ. Sci. Technol., 30, 2580-2585, 1996.

Odum, J. R., Jungkamp, T. P., Griffin, R. J., Flagan, R. C., and Seinfeld, J. H.: The atmospheric aerosol-forming potential of whole gasoline vapor, Science, 276, 96-99, 1997.

Peng, J., Hu, M., Du, Z., Wang, Y., Zheng, J., Zhang, W., Yang, Y., Qin, Y., Zheng, R., Xiao, Y., Wu, Y., Lu, S., Wu, Z., Guo, S., Mao, H., and Shuai, S.: Gasoline aromatics: a critical determinant of urban secondary organic aerosol formation, Atmos. Chem. Phys., 17, 10743-10752, https://doi.org/10.5194/acp-1710743-2017, 2017.

Sarrafzadeh, M., Wildt, J., Pullinen, I., Springer, M., Kleist, E., Tillmann, R., Schmitt, S. H., Wu, C., Mentel, T. F., Zhao, D., Hastie, D. R., and Kiendler-Scharr, A.: Impact of $\mathrm{NO}_{x}$ and $\mathrm{OH}$ on secondary organic aerosol formation from $\beta$ pinene photooxidation, Atmos. Chem. Phys., 16, 11237-11248, https://doi.org/10.5194/acp-16-11237-2016, 2016.

Sato, K., Takami, A., Isozaki, T., Hikida, T., Shimono, A., and Imamura, T.: Mass spectrometric study of secondary organic aerosol formed from the photo-oxidation of aromatic hydrocarbons, Atmos. Environ., 44, 1080-1087, https://doi.org/10.1016/j.atmosenv.2009.12.013, 2010.

Sato, K., Takami, A., Kato, Y., Seta, T., Fujitani, Y., Hikida, T., Shimono, A., and Imamura, T.: AMS and LC/MS analyses of SOA from the photooxidation of benzene and 1,3,5trimethylbenzene in the presence of $\mathrm{NO}_{x}$ : effects of chemical structure on SOA aging, Atmos. Chem. Phys., 12, 4667-4682, https://doi.org/10.5194/acp-12-4667-2012, 2012.

Seinfeld, J. H.: Urban air pollution: State of the science, Science, 243, 745-752, 1989.

Song, C., Na, K., and Cocker III, D. R.: Impact of the hydrocarbon to $\mathrm{NO}_{x}$ ratio on secondary organic aerosol formation, Environ. Sci. Technol., 39, 3143-3149, https://doi.org/10.1021/es0493244, 2005.

Song, C., Na, K., Warren, B., Malloy, Q., and Cocker III, D. R.: Secondary organic aerosol formation from the photooxida- tion of $p$ - and $o$-xylene, Environ. Sci. Technol., 41, 7403-7408, https://doi.org/10.1021/es0621041, 2007.

Sun, J., Wang, Y., Wu, F., Tang, G., Wang, L., Wang, Y., and Yang, Y.: Vertical characteristics of VOCs in the lower troposphere over the North China Plain during pollution periods, Environ. Pollut., 236, 907-915, https://doi.org/10.1016/j.envpol.2017.10.051, 2018.

Tkacik, D. S., Presto, A. A., Donahue, N. M., and Robinson, A. L.: Secondary organic aerosol formation from intermediate-volatility organic compounds: cyclic, linear, and branched alkanes, Environ. Sci. Technol., 46, 8773-8781, https://doi.org/10.1021/es301112c, 2012.

Tong, D., Chen, J. Y., Qin, D. D., Ji, Y. M., Li, G. Y., and An, T. C.: Mechanism of atmospheric organic amines reacted with ozone and implications for the formation of secondary organic aerosols, Sci. Total Environ., 737, 139830, https://doi.org/10.1016/j.scitotenv.2020.139830, 2020.

Volkamer, R., Platt, U., and Wirtz, K.: Primary and secondary glyoxal formation from aromatics: Experimental evidence for the bicycloalkyl-radical pathway from benzene, toluene, and p-xylene, J. Phys. Chem. A, 105, 7865-7874, https://doi.org/10.1021/jp010152w, 2001.

Wang, W. G., Li, K., Zhou, L., Ge, M. F., Hou, S. Q., Tong, S. R., Mu, Y. J., and Jia, L.: Evaluation and Application of Dual-Reactor Chamber for Studying, Acta Phys.-Chim. Sin., 31, 1251-1259, https://doi.org/10.3866/PKU.WHXB201504161, 2015.

Wang, Y., Luo, H., Jia, L., and Ge, S.: Effect of particle water on ozone and secondary organic aerosol formation from benzene- $\mathrm{NO}_{2}-\mathrm{NaCl}$ irradiations, Atmos. Environ., 140, 386394, https://doi.org/10.1016/j.atmosenv.2016.06.022, 2016.

Wyche, K. P., Monks, P. S., Ellis, A. M., Cordell, R. L., Parker, A. E., Whyte, C., Metzger, A., Dommen, J., Duplissy, J., Prevot, A. S. H., Baltensperger, U., Rickard, A. R., and Wulfert, F.: Gas phase precursors to anthropogenic secondary organic aerosol: detailed observations of 1,3,5-trimethylbenzene photooxidation, Atmos. Chem. Phys., 9, 635-665, https://doi.org/10.5194/acp-9635-2009, 2009.

Xu, J., Griffin, R. J., Liu, Y., Nakao, S., and Cocker III, D. R.: Simulated impact of $\mathrm{NO}_{x}$ on SOA formation from oxidation of toluene and $m$-xylene, Atmos. Environ., 101, 217-225, https://doi.org/10.1016/j.atmosenv.2014.11.008, 2015.

Yang, Y., Vance, M., Tou, F., Tiwari, A., Liu, M., and Hochella, M. F.: Nanoparticles in road dust from impervious urban surfaces: distribution, identification, and environmental implications, Environ. Sci.-Nano, 3, 534-544, https://doi.org/10.1039/c6en00056h, 2016.

Zhao, D., Schmitt, S. H., Wang, M., Acir, I.-H., Tillmann, R., Tan, Z., Novelli, A., Fuchs, H., Pullinen, I., Wegener, R., Rohrer, F., Wildt, J., Kiendler-Scharr, A., Wahner, A., and Mentel, T. F.: Effects of $\mathrm{NO}_{x}$ and $\mathrm{SO}_{2}$ on the secondary organic aerosol formation from photooxidation of $\alpha$-pinene and limonene, Atmos. Chem. Phys., 18, 1611-1628, https://doi.org/10.5194/acp18-1611-2018, 2018.

Zhou, Y., Zhang, H., Parikh, H. M., Chen, E. H., Rattanavaraha, W., Rosen, E. P., Wang, W., and Kamens, R. M.: Secondary organic aerosol formation from xylenes and mixtures of toluene and xylenes in an atmospheric urban hydrocarbon mixture: Water 
and particle seed effects (II), Atmos. Environ., 45, 3882-3890, https://doi.org/10.1016/j.atmosenv.2010.12.048, 2011.

Ziemann, P. J.: Effects of molecular structure on the chemistry of aerosol formation from the OH-radical-initiated oxidation of alkanes and alkenes, Int. Rev. Phys. Chem., 30, 161-195, https://doi.org/10.1080/0144235x.2010.550728, 2011.
Zou, Y., Deng, X. J., Zhu, D., Gong, D. C., Wang, H., Li, F., Tan, H. B., Deng, T., Mai, B. R., Liu, X. T., and Wang, B. G.: Characteristics of 1 year of observational data of VOCs, $\mathrm{NO}_{x}$ and $\mathrm{O}_{3}$ at a suburban site in Guangzhou, China, Atmos. Chem. Phys., 15, 6625-6636, https://doi.org/10.5194/acp-15-6625-2015, 2015. 